\title{
DNA-intercalators Causing Rapid Re-expression of Methylated and Silenced Genes in Cancer Cells
}

\author{
M. Zulfiquer Hossain ${ }^{1}$, Megan A. Healey ${ }^{1}$, Calvin Lee ${ }^{1}$, Weijie Poh $^{1}$, Sashidhar R. \\ Yerram $^{1}$, Kalpesh Patel ${ }^{1}$, Nilofer S. Azad ${ }^{1}$, James G. Herman ${ }^{1}$, and Scott E. Kern ${ }^{1}$ \\ 1 Sidney Kimmel Comprehensive Cancer Center, Department of Oncology, Johns Hopkins University School of Medicine, \\ Baltimore, Maryland \\ Correspondence to: Scott E. Kern, email: sk@jhmi.edu \\ Keywords: cancer, gene methylation, demethylation, DNA-intercalator, quinacrine, DNMT inhibitor, epigenetics, silencing and re- \\ activation of gene expression, small molecule-DNA interactions \\ Received: February 8, $2013 \quad$ Accepted: February 25, $2013 \quad$ Published: February 26, 2013
}

This is an open-access article distributed under the terms of the Creative Commons Attribution License, which permits unrestricted use, distribution, and reproduction in any medium, provided the original author and source are credited.

\section{ABSTRACT:}

Epigenetic inactivation of tumor-suppressor and other regulatory genes plays a critical role in carcinogenesis. Transcriptional silencing is often maintained by DNA methyl transferase (DNMT)-mediated hypermethylation of CpG islands in promoter DNA. Nucleoside analogs including azacytidine and decitabine have been used to inhibit DNMT and re-activate genes, and are clinically used. Their shortcomings include a short half-life and a slow onset of action due to required nucleotide incorporation during DNA replication, which may limit clinical utility. It might be useful to begin to identify lead compounds having novel properties, specifically distinct and fast-acting gene desilencing. We previously identified chemicals augmenting gene expression in multiple reporter systems. We now report that a subset of these compounds that includes quinacrine re-expresses epigenetically silenced genes implicated in carcinogenesis. p16, TFPI2, the cadherins E-cadherin and CDH13, and the secreted frizzle-related proteins (SFRPs) SFRP1 and SFRP5 were desilenced in cancer cell lines. These lead compounds were fast-acting: re-expression occurred by 12-24 hours. Reactivation of silenced genes was accompanied by depletion of DNMT1 at the promoters of activated genes and demethylation of DNA. A model compound, 5175328, induced changes more rapidly than decitabine. These gene desilencing agents belonged to a class of acridine compounds, intercalated into DNA, and inhibited DNMT1 activity in vitro. Although to define the mechanism would be outside the scope of this initial report, this class may re-activate silenced genes in part by intercalating into DNA and subsequently inhibiting full DNMT1 activity. Rapid mechanisms for chemical desilencing of methylated genes therefore exist.

\section{INTRODUCTION}

Genes silenced in cancer comprise tumorsuppressor genes, regulatory genes, and genes involved in differentiation. These genes are often inactivated by epigenetic mechanisms involving methylation of cytosines in $\mathrm{CpG}$ islands of promoter DNA, higher-order heritable chromatin folding/remodeling, and modifications on histone proteins 3 and 4 [1]. Histone tail modifications include acetylation, phosphorylation, lysine or arginine methylation, ubiquitylation, glycosylation, sumoylation, and ADP-ribosylation [2, 3]. These modifications are individually associated with gene activation or repression and are collectively known as the histone code. Because epigenetic changes are potentially reversible, they provide attractive targets for cancer therapy. Reprogramming of epigenetic controls is also an emerging strategy for in vitro development of stem cells and for generating therapeutically useful differentiated cell types [4]. Demethylating agents currently in use, e.g. azacytidine and decitabine (5-aza-2'-deoxycytidine), are nucleoside analogs. They demethylate promoter DNA slowly because 
they require incorporation into DNA during cell division and subsequent depletion of DNA methyl transferases (DNMTs) through irreversible binding of these proteins [5]. Their limited efficacy in culture and in treating solid tumors has, however, partially been addressed by cotreatment with histone deacetylase (HDAC) inhibitors such as trichostatin A (TSA) [6].

When exploring compounds for therapeutic functions, the identification of novel properties in lead compounds is an endeavor preceding the subsequent optimization to create a drug. Because the identified lead

A

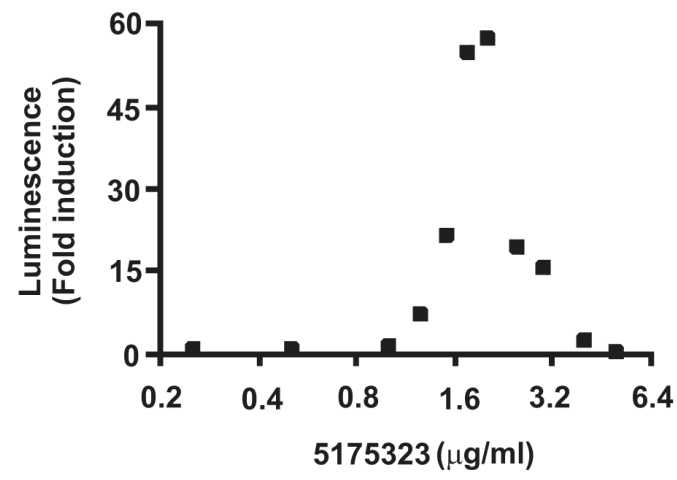

B

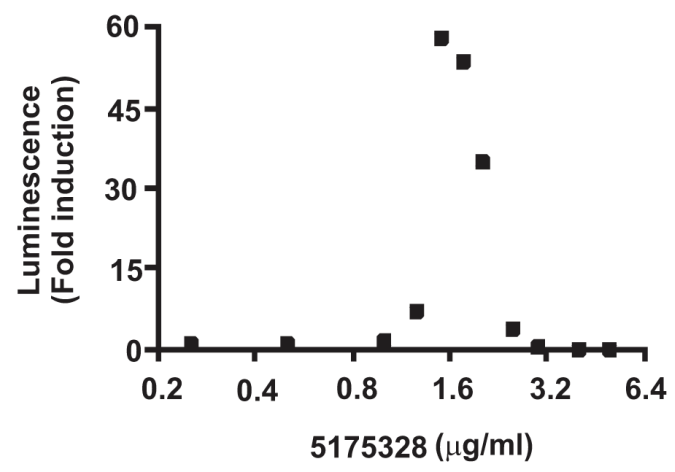

C

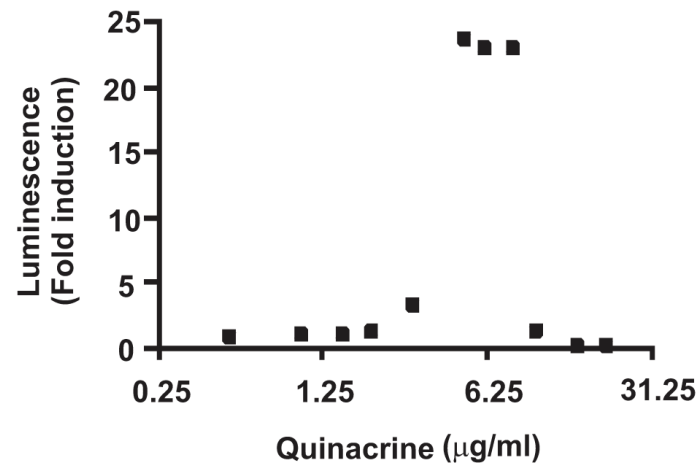

Figure 1: Acridine compounds enhanced nonspecific gene expression. Luciferase assays were performed on $\mathrm{CHO}$ AA8-Luc Tet-Off cells 18 hours after treatment with compounds 5175323 (A), 5175328 (B), or quinacrine (C). Cells were plated in quadruplicate for each treatment. Data from representative experiments are shown. compounds initially tend to have toxicity/off-target effects and relatively low potency and efficacy, optimization can be a long and expensive process. These two endeavors are discrete. Here, we provide lead compounds so as to begin to explore new properties by which gene desilencing can be accomplished.

From high-throughput cell-based screening, we previously identified eleven compounds that nonspecifically elevated the activity of multiple reporter systems tested [7]. Quinacrine, 1-phenyl-3-(2-thiazolyl)-2thiourea, piperine, apigenin, and ChemBridge compounds 5100018, 5110235, 5175323, 5175324, 5175328, 5234881 , and 5238219 indiscriminately activated gene expression. The activation property was shared among more than one of the following seven reporter systems: Smad4R, RKO p53R, HCT116 p53R, DLD/BFP, CHOAA8, Shh FF, and Shh REN. Of the eleven agents listed above, four are structurally similar acridine compounds: 5175323, 5175324, 5175328, and quinacrine. These four share a hetero-tri-cyclic functional group known to intercalate into DNA [8] and produced the greatest induction of the reporter systems studied [7]. We therefore set out to determine whether these compounds could be used in cancer cell lines to re-activate methylated and silenced genes that had been implicated in carcinogenesis. We found that acridine compounds could rapidly desilence genes without any apparent requirement for incorporation into DNA. We thus identified a class of lead compounds with novel useful properties which could be optimized in the future for anticancer effects and reprogramming of gene expression.

\section{RESULTS}

\section{Chemicals nonspecifically enhancing gene expression}

To extend our prior results [7], CHO AA8-Luc Tet-Off cells were plated and quadruplicate wells treated with each chemical at each of various concentrations for 18 hours. In these cells, luciferase expression is driven by the constitutively active cytomegalovirus (CMV) promoter. Therefore, luciferase assays were used to measure the effect of treatment on nonspecific gene expression. 5175324 could not be tested because it was not readily available. Five chemicals produced highly robust induction (greater than 10-fold) of the reporter system, indicating indiscriminate elevation of gene expression: TSA, Scriptaid, 5175323, 5175328, and quinacrine. The greatest reporter activity was seen using $0.5-5 \mu \mathrm{g} / \mathrm{ml}$ for TSA, $2-10 \mu \mathrm{g} / \mathrm{ml}$ for Scriptaid, $2 \mu \mathrm{g} / \mathrm{ml}$ for 5175323,1 $-2 \mu \mathrm{g} / \mathrm{ml}$ for 5175328 (all replicated multiple times with similar findings), and $5 \mu \mathrm{g} / \mathrm{ml}$ for quinacrine (replicated with similar findings). Lesser induction (less than 10- 
Table 1: Compounds

\begin{tabular}{ccc}
$\begin{array}{c}\text { Expanded } \\
\text { nomenclature }\end{array}$ & $\begin{array}{c}\text { Acridin-9-yl-[4- } \\
\text { (4-methyl- } \\
\text { piperazin-1-yl)- } \\
\text { phenyl]-amine }\end{array}$ & $\begin{array}{c}\text { Range for re- } \\
\text { expression }(\mu \mathrm{mg} / \mathbf{m l})\end{array}$ \\
\hline 5175328 & $0.5-5$
\end{tabular}

fold) was observed with other chemicals tested: 5100018 , 5234881, and 5238219. These findings were consistent with prior work [7].

Of the five chemicals causing significant induction, TSA and Scriptaid are well established as histone deacetylase inhibitors [9]. The rest belong to the same class of acridine compounds (Table 1). Intrigued by their strong ability to nonspecifically enhance gene expression, we decided to study these compounds (5175323, 5175328, and quinacrine) in greater detail and used dose-response curves to determine the desired range of concentrations for further studies (Fig. 1).

\section{Attempts to re-activate specific methylated and silenced genes in cancer cell lines}

In an attempt to re-express specific methylationsilenced genes, we treated several randomly chosen cancer cell lines with various concentrations of each acridine compound for 24 hours. We found that 5175323 (Fig. 2A) and quinacrine (Fig. 2C) both re-expressed CDH13, E-cadherin, SFRP1, and TFPI2 in MiaPaCa2 pancreatic cells (replicated with similar findings). 5175323 (Fig. 2B) and quinacrine (Fig. 2D) also re-activated p16,
SFRP1, and SFRP5 in RKO colorectal cells (replicated with similar results). 5175328 (Fig. 3) re-expressed CDH13, E-cadherin, SFRP1, and TFPI2 in MiaPaCa2 cells (replicated multiple times with similar findings), but it did not re-activate BNIP3 in the same cells. Similarly, 5175328 (Fig. 2E) desilenced SFRP1 and SFRP5 in RKO cells (replicated with similar observations), but did not re-activate p16 in the same cells. Finally, 5175328 (Fig. 2F) re-expressed SFRP1, SFRP5, and TFPI2 in HCT-116 (colorectal) cells (replicated with similar findings). Sporadic failures to re-express were seen occasionally (Fig. 2C), but re-expression was observed over a continuous range of drug concentration in other experiments. We thus showed that acridine compounds desilenced genes in cancer cells (Table 2).

\section{Specificity: Chemotherapeutic agents do not have a general ability to cause gene re-expression}

To address the possibility that gene desilencing was simply a consequence of toxicity or DNA damage, we tested several chemotherapeutic drugs for their ability to induce reporter activity in $\mathrm{CHO}$ AA8-Luc Tet-Off cells or desilence genes in $\mathrm{MiaPaCa} 2$ cells. Etoposide, 
5-fluorouracil (5-FU), mitomycin $\mathrm{C}$, and quercetin caused moderate to negligible induction of the reporter system (less than 10-fold induction) in CHO AA8-Luc Tet-Off cells (Etoposide: 4.5-8.3 fold, 5-fluorouracil (5FU): 2.4 fold, mitomycin C: 1.5 fold, and quercetin: 1.3 fold). Also, none of these drugs re-activated E-cadherin, SFRP1, or TFPI2 in MiaPaCa 2 cells. We concluded that DNA-damaging agents had little ability to enhance gene expression specifically or nonspecifically.

\section{Rapid onset of effect}

Next, we determined the time-course of gene reactivation by 5175328 (our model acridine compound) in $\mathrm{MiaPaCa} 2$ cells. We did not see any gene re-expression after 6 hours of treatment. However, 5175328 induced reexpression of CDH13, E-cadherin, SFRP1, and TFPI2 as

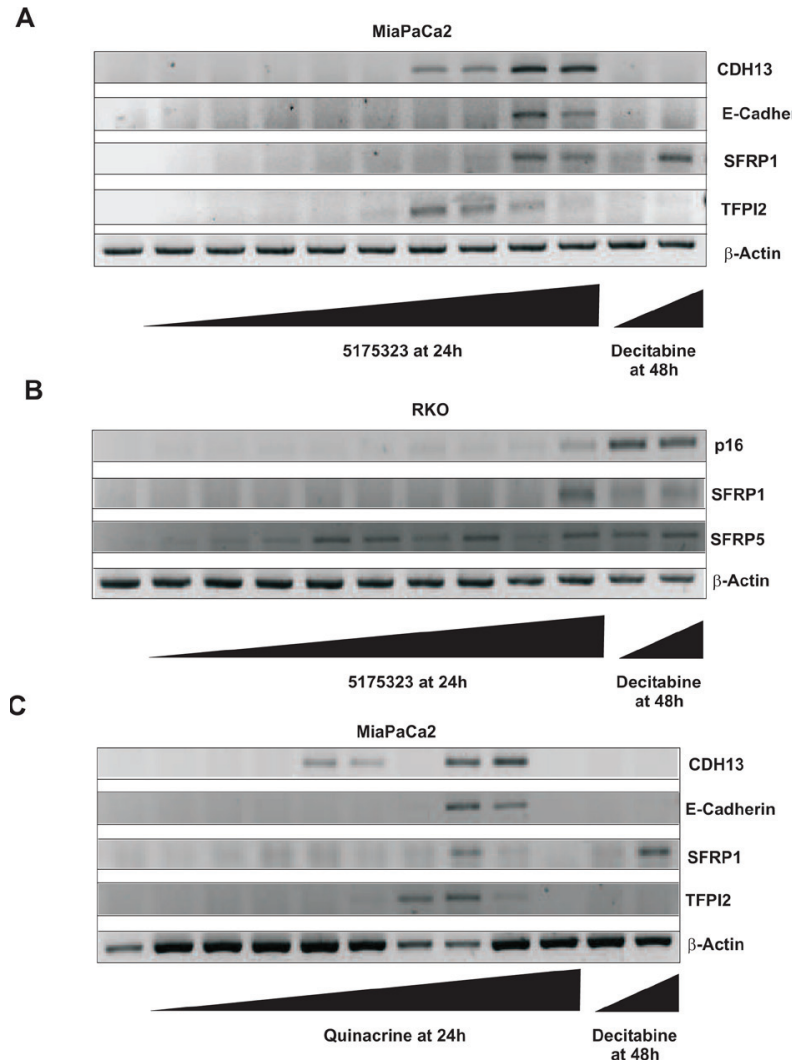

early as 12 hours after treatment (Fig. 3). The level of reexpression diminished at 48 hours after treatment (Fig. 3).

\section{Preliminary mechanistic explorations}

The focus of these studies was to identify genedesilencing agents having novel properties, described above. Although outside the fundamental scope of a report of lead compounds, we also performed limited mechanistic explorations that could help explain the class of compounds indentified and orient future research into optimized compounds. It is these later-generation compounds, which would reflect optimization for potency, specificity, and efficacy, that would provide the most suitable agents for defining mechanisms of action. With these caveats, the results of brief mechanistic explorations of the lead compounds are provided below.
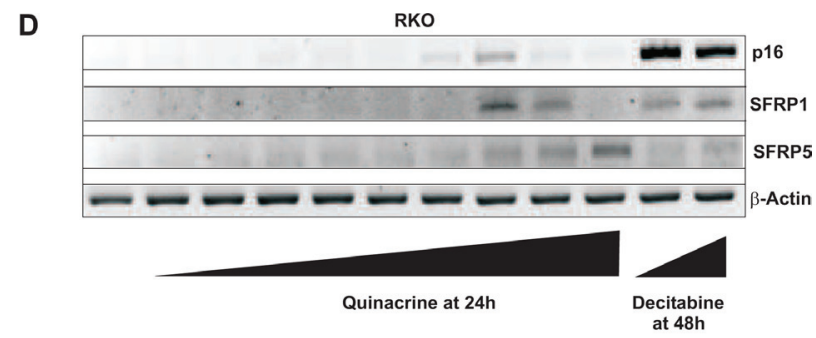

$\mathbf{E}$

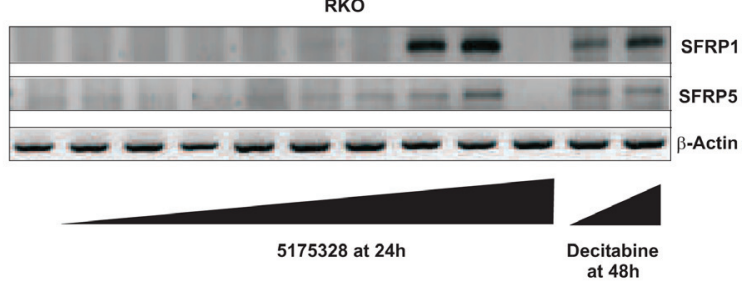

$\mathbf{F}$

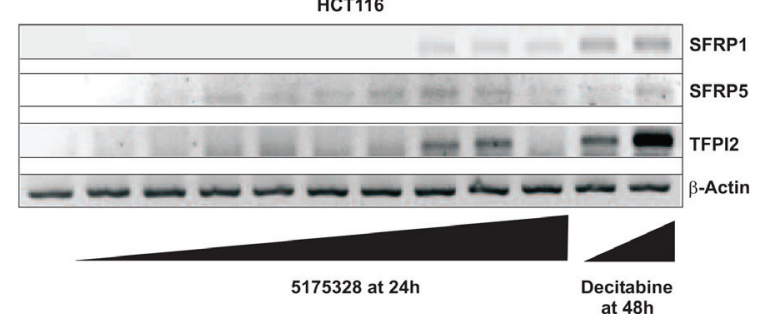

Figure 2: Acridine compounds re-activated methylated and silenced genes in cancer cell lines in a dose-dependent fashion. Cells were treated with an acridine compound for 24 hours or with decitabine for 48 hours with drug and medium replaced 24 hours after the beginning of treatment. RNA extracted from the cells was subjected to RT-PCR analysis. $\beta$-actin was used as an internal control. A, Compound 5175323 induced gene re-expression in MiaPaCa2 cells. Re-expressed genes: CDH13, E-cadherin, SFRP1, and TFPI2. 5175323 concentrations $(\mu \mathrm{g} / \mathrm{ml}): 0.01,0.1,1,1.5,2,2.5,3,4$, and 5. Decitabine concentrations $(\mu \mathrm{M}): 1$ and 5 . B, 5175323 induced gene re-expression in RKO cells. Re-expressed genes: p16, SFRP1, and SFRP5. 5175323 concentrations ( $\mu \mathrm{g} / \mathrm{ml}): 0.01,0.1,1,1.5,2$, 2.5, 3, 4, and 5. Decitabine concentrations $(\mu \mathrm{M}): 1$ and 5. C, Quinacrine induced gene re-expression in MiaPaCa2 cells. Re-expressed genes: CDH13, E-cadherin, SFRP1, and TFPI2. Quinacrine concentrations ( $\mu \mathrm{g} / \mathrm{ml}): 0.01,0.1,1,2,3,5,8,10$, and 20. Decitabine concentrations $(\mu \mathrm{M}): 1$ and 5. D, Quinacrine induced gene re-expression in RKO cells. Re-expressed genes: p16, SFRP1, and SFRP5. Quinacrine concentrations $(\mu \mathrm{g} / \mathrm{ml}): 0.01,0.1,1,2,3,5,8,10$, and 20. Decitabine concentrations $(\mu \mathrm{M}): 1$ and 5 . E, 5175328 induced gene re-expression in RKO cells. Re-expressed genes: SFRP1 and SFRP5. 5175328 concentrations ( $\mu \mathrm{g} / \mathrm{ml}): 0.01,0.05,0.1,0.25,0.5,1,1.5,2$, 5. Decitabine concentrations $(\mu \mathrm{M}): 1$ and 5. F, 5175328 induced gene re-expression in HCT116 cells. Re-expressed genes: SFRP1, SFRP5, and TFPI2. 5175328 concentrations $(\mu \mathrm{g} / \mathrm{ml}): 0.01,0.05,0.1,0.25,0.5,1,1.5,2,5$. Decitabine concentrations $(\mu \mathrm{M}): 1$ and 5 . 
Table 2: Re-expression of methylation-silenced genes

\begin{tabular}{|l|l|l|l|l|}
\hline \multirow{2}{*}{ Gene } & \multirow{2}{*}{ Silenced in } & \multicolumn{3}{|l|}{ \# of cell lines re-expressing (of \# tested) } \\
\cline { 3 - 5 } & & 5175328 & 5175323 & Quinacrine \\
\hline CDH13 & MiaPaCa2 & $1(1)$ & $1(1)$ & $1(1)$ \\
\hline E-cadherin & MiaPaCa2 & $1(1)$ & $1(1)$ & $1(1)$ \\
\hline p16 & RKO & $0(1)$ & $1(1)$ & $1(1)$ \\
\hline SFRP1 & $\begin{array}{l}\text { HCT116, MiaPaCa2, } \\
\text { RKO }\end{array}$ & $3(3)$ & $2(2)$ & $2(2)$ \\
\hline SFRP5 & HCT116, RKO & $2(2)$ & $1(1)$ & $1(1)$ \\
\hline TFPI2 & HCT116, MiaPaCa2 & $2(2)$ & $1(1)$ & $1(1)$ \\
\hline
\end{tabular}

\section{Gene re-expression is accompanied by DNA demethylation and reduced DNMT1 localization at specific promoters}

In an effort to explore possible modes of action, we used methylation-specific PCR (MSP) to examine the methylation status of re-activated promoters after 5175328 treatment since previous studies had established DNA methylation as a mechanism for silencing these genes [10-15]. 5175328 induced dose- and time-dependent demethylation of CDH13, E-cadherin, and SFRP1 promoters in $\mathrm{MiaPaCa} 2$ cells. This process began by 6 hours at the CDH13 promoter, 12 hours at the SFRP1 promoter, and 18 hours at the E-cadherin promoter (Fig. 4A). It peaked around 24 hours in all three promoters (Fig. 4A). Evidence for 5175328-dependent demethylation was ambiguous at the desilenced TFPI2 promoter in MiaPaCa2 cells since this gene was only partially methylated prior to treatment. 5175328 consistently induced these changes more rapidly and robustly than decitabine (Fig. 4A). The evidence also suggested dose-dependent demethylation of the SFRP1 promoter in RKO cells after 24 hours of 5175328 treatment (Fig. 4B). However, we could not detect 5175328-mediated demethylation at the re-activated SFRP5 promoter in RKO cells, which was also partially methylated at baseline. Consistent with the failure of 5175328 to re-activate p16 in RKO cells, we did not see evidence for demethylation of the p16 promoter in the same cells. It is conceivable that 5175328 re-activated some genes by alternative mechanisms or that baseline incomplete methylation made detection of small degrees of demethylation challenging.

5175328-induced demethylation of the SFRP1 promoter was confirmed to affect $\mathrm{CpG}$ dinucleotides by bisulfite sequencing in $\mathrm{RKO}$ and $\mathrm{MiaPaCa} 2$ cells (Supplementary Fig. S1). We analyzed $58 \mathrm{CpG}$ sites from the SFRP1 promoter in both cell lines. The average number of demethylated $\mathrm{CpG}$ sites per DNA molecule increased after treatment with 5175328. Patches of adjacent demethylated $\mathrm{CpG}$ dinucleotides also were observed after treatment. Considering the methylationspecific PCR results and the pattern observed using bisulfite sequencing, 5175328-mediated re-expression of methylation-silenced genes appeared to be accompanied by a degree of rapid promoter demethylation for the majority of genes tested.

We thus wondered whether 5175328 affected global DNMT1 protein quantity, as was observed following treatment of cells with decitabine or azacytidine [16]. We evaluated the effects of 5175328 on DNMT1 protein level and histone acetylation in $\mathrm{MiaPaCa} 2$ cells by western blot (replicated with similar observations). TSA-treated $\mathrm{MiaPaCa} 2$ cells served as a positive control for histone acetylation (Fig. 4C). We found that the amount of DNMT1 protein decreased in MiaPaCa2 cells after higherdose 5175328 treatment at 12 hours and 24 hours (Fig. 4C). Interpretation of this finding was, however, complicated by the observation that etoposide and mitomycin $\mathrm{C}$ also reduced global DNMT1 protein level in MiaPaCa2 cells without inducing re-expression of methylation-silenced genes. This suggests that depletion of DNMT1 at a global level might not always lead to gene desilencing and may be secondary to inhibition of proliferation, proliferation being associated with DNMT1 expression. We observed a decrease in global histone acetylation after treatment of MiaPaCa2 cells with 5175328 (Fig. 4C), suggesting that inhibition of histone deacetylases was unlikely to be its mechanism of action as this would increase global histone acetylation.

Next, we sought to determine the effect of 5175328 on the localization of DNMT1 to specific re-activated promoters, using the chromatin immunoprecipitation (ChIP) assay (each experiment performed twice with similar findings and PCRs performed in triplicate for each experiment). We saw a decrease in the amount of DNMT1 associated with specific promoters after treatment of MiaPaCa2 cells with 5175328 for 24 hours (Fig. 4D). For example, 5175328 reduced the level of DNMT1 at CDH13, E-cadherin, and SFRP1 promoters (Fig. 4D). A similar pattern of DNMT1 localization was observed at a second site in the SFRP1 promoter. Consistent with the failure to detect any change in demethylation at the TFPI2 promoter, the amount of DNMT1 localized to this promoter did not decrease with 5175328 treatment. Also, in accordance with the pattern of TFPI2 re-expression, the level of histone acetylation peaked after low-dose 5175328 treatment and declined at a higher dose. There was a decrease in the amount of histone acetylation at 
CDH13 and SFRP1 promoters (Fig. 4D). The pattern of histone acetylation was similar at a second site in the SFRP1 promoter. At the E-cadherin promoter, 5175328 treatment increased the level of histone acetylation at a low dose (correlating with gene re-expression in Fig. 3) and decreased it at a higher dose (Fig. 4D). In summary, 5175328 induced depletion of DNMT1 at specific desilenced promoters, undergoing demethylation. The effect on histone acetylation was variable.

\section{Acridine compounds intercalate into DNA and inhibit DNMT1 activity in vitro}

Because 5175328 treatment led to the appearance of demethylated promoter DNA, we inquired whether it could directly inhibit DNMT1 in vitro. We assayed the ability of DNMT1 to methylate a DNA substrate in the presence of various concentrations of 5175328, 5175323, and quinacrine (each experiment replicated multiple times with similar findings and assays performed in duplicate for each experiment). Increasing concentrations of 5175328 , 5175323, and quinacrine reduced DNMT1 activity (Fig. 5A). 5-fluorouracil, a negative control, had no effect on DNMT1 activity (Fig. 5A). Acridine compounds thus inhibited DNMT1 activity in vitro in a dose-dependent manner.

To explore a potential mechanism by which acridine compounds might inhibit the DNA-interacting enzyme DNMT1, we assayed DNA intercalation in vitro (replicated with similar results). Briefly, closed, circular plasmid DNA was incubated with each compound for 5 minutes. Ethidium bromide was used as a positive control. 5238219 lacking the hetero-tri-cyclic acridine ring, served as a negative control (Fig. 5B). Increasing concentrations of 5175328, 5175323, and quinacrine retarded the migration of plasmid DNA (Fig. 5B). 5175328 at $5 \mu \mathrm{g} /$ $\mathrm{ml}$ caused the same degree of retardation as $5 \mu \mathrm{g} / \mathrm{ml}$ ethidium bromide (Fig. 5B). Higher concentrations of 5175328 resulted in greater retardation, while the effect of ethidium bromide reached a maximum (Fig. 5B). 5175323 at $500 \mu \mathrm{g} / \mathrm{ml}$ and quinacrine at $50 \mu \mathrm{g} / \mathrm{ml}$ induced retardation similar to $5 \mu \mathrm{g} / \mathrm{ml}$ ethidium bromide (Fig. $5 \mathrm{~B})$. We concluded that acridine compounds could swiftly intercalate into DNA in a dose-dependent manner.

\section{DISCUSSION}

Our findings suggested that specific acridine compounds rapidly re-activate expression of methylated and silenced genes at $\mu \mathrm{g} / \mathrm{ml}$ concentrations (5175328: 0.5 $-5 \mu \mathrm{g} / \mathrm{ml}, 5175323: 1-5 \mu \mathrm{g} / \mathrm{ml}$, and quinacrine: $2-20$ $\mu \mathrm{g} / \mathrm{ml})$. A possible mechanism would be the demethylation of promoter $\mathrm{CpG}$ islands due to intercalation of the compound into DNA and subsequent inhibition and depletion of DNMT1 at the desilenced promoter. Other, not yet explored, mechanisms might also be involved, and the process of demethylation may be complex. For example, increasing concentrations of a model acridine compound lead to progressive DNA demethylation and DNMT1 depletion at specific promoters, but gene re-expression was lost beyond an optimal concentration. These higher concentrations were also associated with growth arrest. Since inhibition and depletion of DNMT1 would result in demethylation only if cell division occurred (passive demethylation), progressive demethylation in the absence of cell proliferation would suggest a possible role for nonpassive modes of DNA demethylation. Another intriguing observation was the absence of DNMT1 depletion or any detectable change in DNA methylation at the re-activated TFPI2 promoter, allowing for alternative mechanisms of gene desilencing.

Coincidentally, 5175328, a model intercalating agent, is also a highly selective $\alpha_{2 \mathrm{C}}$-adrenoceptor antagonist at low $\mathrm{nM}$ concentrations with anti-depressant and antipsychotic properties [17]. Some of the observed

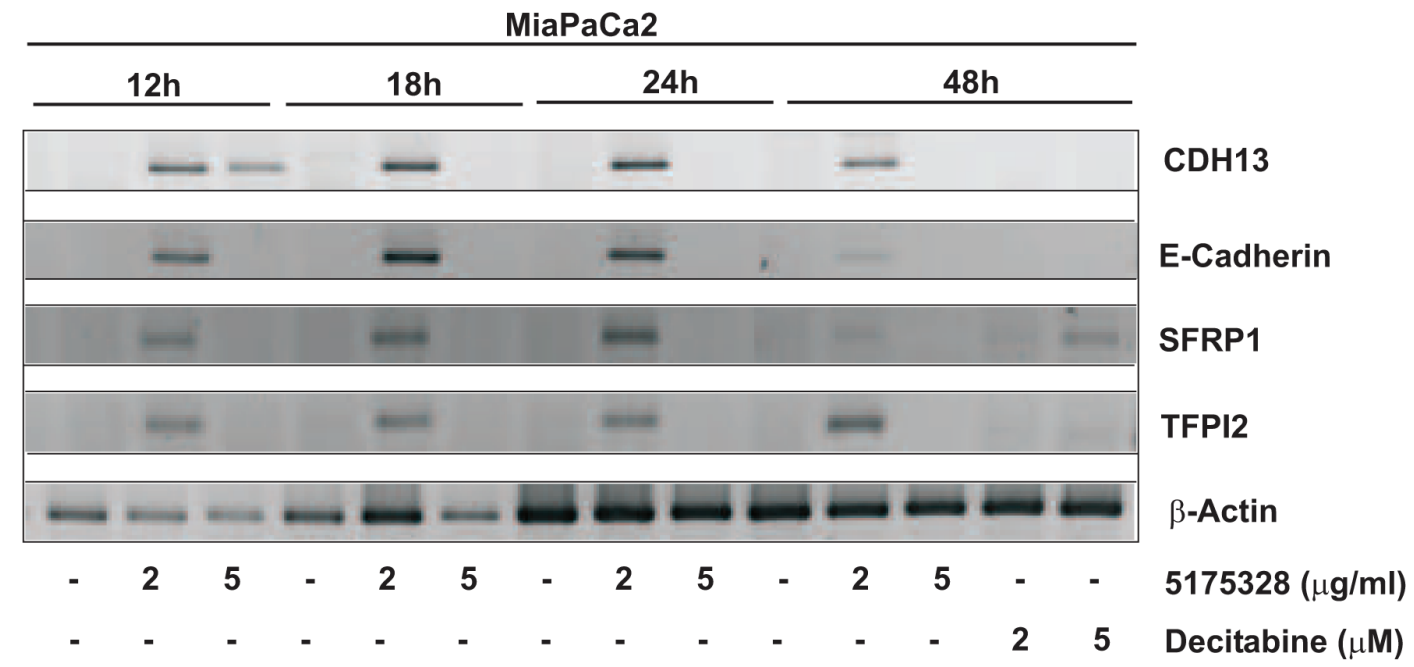

Figure 3: Compound 5175328 re-activated gene expression as early as 12 hours after treatment. Re-expressed genes as detected by RT-PCR analysis: CDH13, E-cadherin, SFRP1, and TFPI2. 
pharmacologic properties of 5175328 at higher doses, however, might include its ability to affect gene expression.

Quinacrine is known to act as a potent inhibitor of histamine N-methyl transferase [18]. It is also reported to have anticancer activity at $\mu \mathrm{M}$ concentrations, synergizing with 5-fluorouracil in inducing apoptosis of colorectal cancer cells [19], rendering hepatocellular carcinoma cells susceptible to TRAIL-induced apoptosis [20], and enhancing toxicity of other chemotherapeutic agents [20]. The mechanisms for these effects are unknown. Our results suggest a new possible mechanism, for quinacrine might exert some of its anticancer effects in part by inhibiting another methyl transferase DNMT1 and affecting DNA methylation, which could alter the expression of genes affecting the sensitivities to other chemotherapies.

A

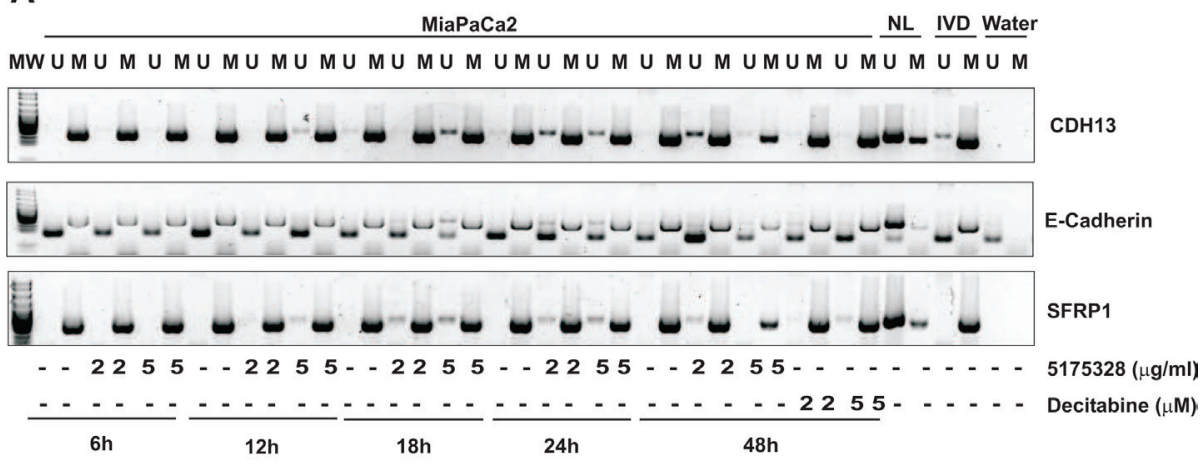

B

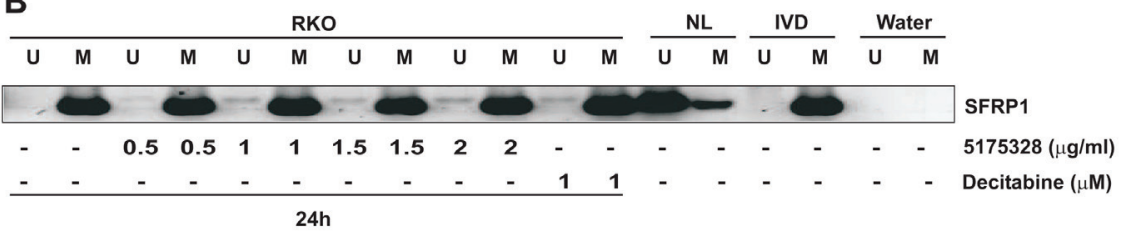

C

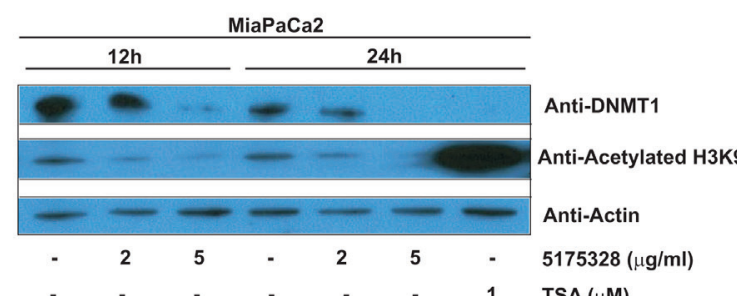

D

DNMT1

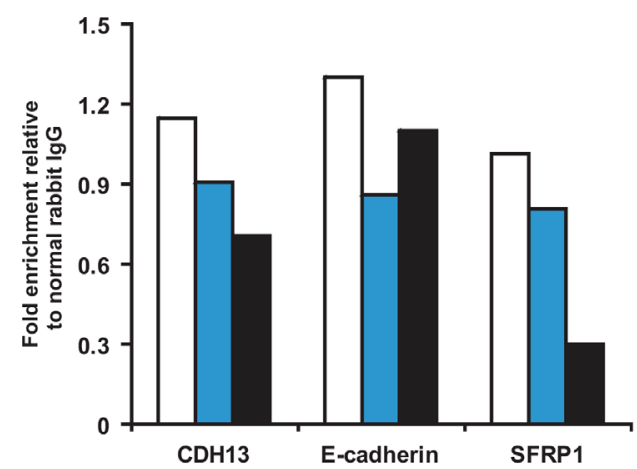

TSA $(\mu \mathrm{M})$

H3K9Ac

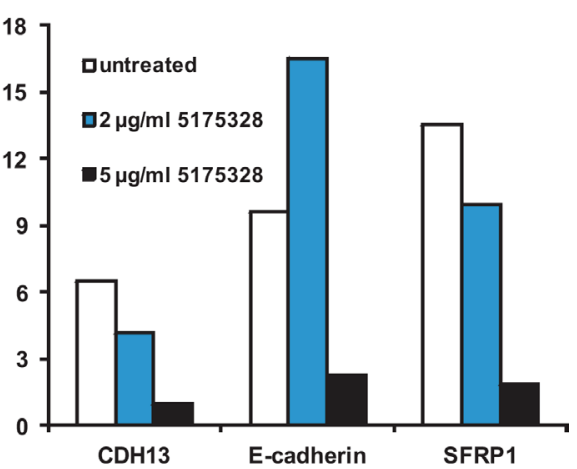

Figure 4: Compound 5175328-mediated gene re-expression appeared to be accompanied by DNA demethylation and DNMT1 depletion at specific promoters. A, 5175328 appeared to induce DNA demethylation at CDH13, E-cadherin, and SFRP1 promoters in MiaPaCa2 cells in a dose- and time-dependent manner. U, unmethylated allele; M, methylated allele. Normal human lymphocytes (NL), in vitro methylated DNA (IVD), and water were included as controls. B, 5175328 appeared to induce DNA demethylation at the SFRP1 promoter in RKO cells. U, unmethylated allele; M, methylated allele. Normal human lymphocytes (NL), in vitro methylated DNA (IVD), and water were included as controls. C, DNMT1 quantity and histone acetylation in MiaPaCa2 cells after 5175328 treatment, assayed by western blot. D, DNMT1 localization and histone acetylation at CDH13, E-cadherin, and SFRP1 promoters in $\mathrm{MiaPaCa} 2$ cells after 5175328 treatment, assessed by ChIP. PCR assays were performed in triplicate. Data from a representative ChIP experiment are shown. 
Nucleoside DNMT inhibitors such as azacytidine, decitabine (5-aza-2'-deoxycytidine), SG-110 (decitabine prodrug), 5-fluoro-2-deoxycytidine, and zebularine have been used effectively to inhibit DNA methyl transferase and re-express silenced genes. Azacytidine and decitabine have been approved for use in the treatment of myelodysplastic syndrome (MDS), but have properties that may limit their use. They may mutagenize due to DNA strand breaks $[5,21]$. They have a short half-life in vivo, and yet require at least 48 hours of treatment in culture even for low-level gene re-activation [6]. Their use is characterized by a slow onset of the demethylated state because they require covalent incorporation into DNA during an initial cell division, prior to any inhibition of DNMTs during a subsequent cell division [5]. Thus, at least three cell divisions are required for demethylation of both strands of DNA to be accomplished. To provide a more efficient reversal of gene silencing, HDAC inhibitors including SAHA (Vorinostat), Belinostat,
Entinostat, TSA, Panobinostat, phenyl butyrate, sodium butyrate, valproic acid, Scriptaid, and Romidepsin have been used in conjunction with azacytidine and decitabine [22]. However, HDAC inhibitors cannot be used alone to desilence methylated genes [6]. Polyamine LSD1 (a protein lysine demethylase) inhibitors have also been used to re-express genes, but they were found to be less effective than decitabine [23]. Among histone-lysinemethyl transferase inhibitors, EZH2 inhibitors like 3-Deazaneplanocin A (DZNep) and Sinefungin and G9a (EHMT2) inhibitors like BIX-01294 and 8 (UNC0224) [24] have been used for gene desilencing. Several classes of topoisomerase inhibitors re-activate the dormant allele of Ube3a in neurons [25]. These classes include camptothecin derivatives, indenoisoquinoline derivatives, bis-dioxopiperazine derivatives, the podophyllotoxin derivative etoposide, and the aminoacridine derivative amsacrine [25]. DNA intercalation might plausibly be involved in their desilencing effect, based upon the

\section{A}

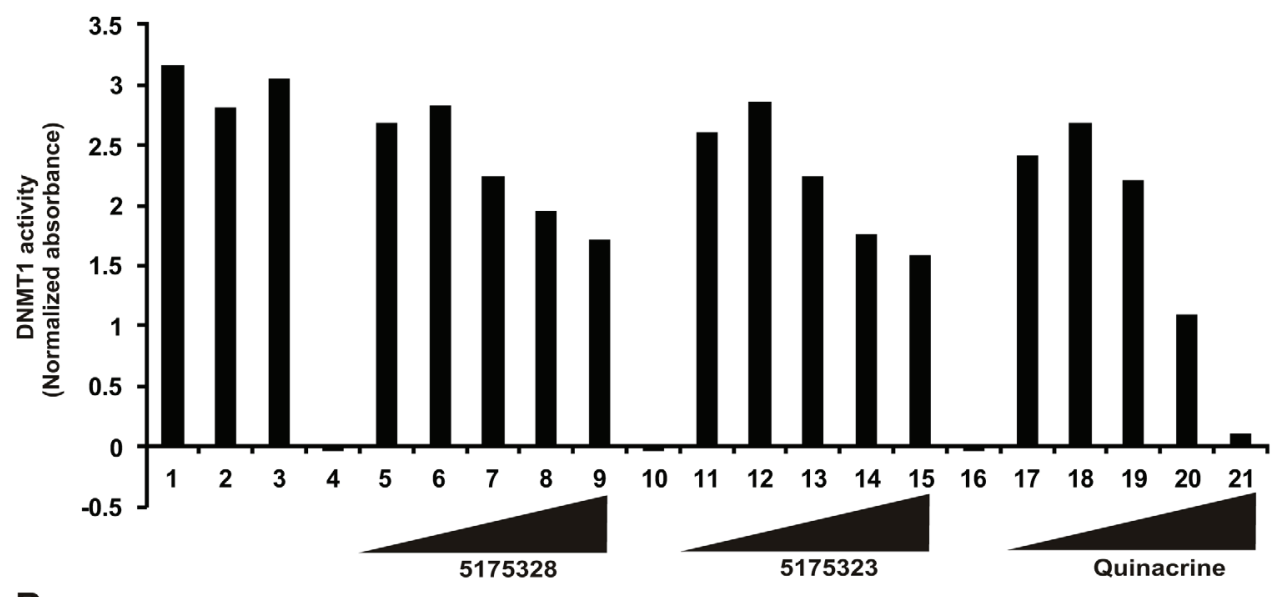

B
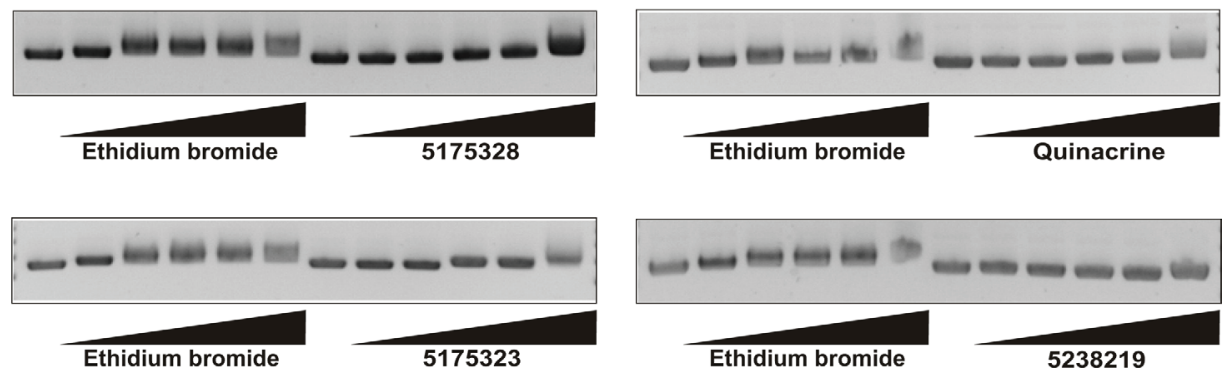

Figure 5: Acridine compounds intercalate into DNA and inhibit DNMT1 activity in vitro. A, DNMT1 activity assay in the presence of compounds 5175328, 5175323, and quinacrine. 5-fluorouracil (5-FU) was a negative control. Each assay was performed in duplicate in every experiment. Data from a representative experiment are shown. Normalized absorbance was calculated by subtracting the $655 \mathrm{~nm}$ OD from the $450 \mathrm{~nm}$ OD. Full description of each bar: DNMT1 (1), DNMT1+DMSO (2), DNMT1 + $100 \mu$ M 5 FU (3), 10

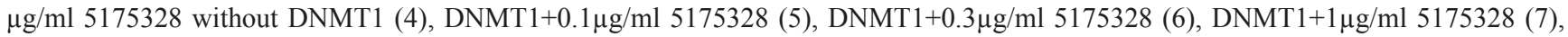
DNMT1 $+3 \mu \mathrm{g} / \mathrm{ml} 5175328$ (8), DNMT1 + $10 \mu \mathrm{g} / \mathrm{ml} 5175328$ (9), $10 \mu \mathrm{g} / \mathrm{ml} 5175323$ without DNMT1 (10), DNMT1+0.1 $4 \mathrm{~g} / \mathrm{ml} 5175323$

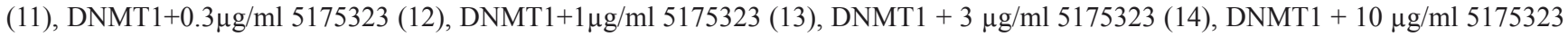
(15), $100 \mu \mathrm{g} / \mathrm{ml}$ quinacrine without DNMT1 (16), DNMT1 $1 \mu \mathrm{g} / \mathrm{ml}$ quinacrine (17), DNMT1+3 $\mu \mathrm{g} / \mathrm{ml}$ quinacrine (18), DNMT1+10 $\mu \mathrm{g} /$ $\mathrm{ml}$ quinacrine (19), DNMT1 $+30 \mu \mathrm{g} / \mathrm{ml}$ quinacrine (20), DNMT1 + $100 \mu \mathrm{g} / \mathrm{ml}$ quinacrine (21). B, DNA intercalation assay of 5175328, 5175323, and quinacrine. Ethidium bromide was a positive control, and 5238219 a negative control. For each compound the following concentrations were used $(\mu \mathrm{g} / \mathrm{ml}): 0.1,1,5,50$, and 500 . 
observations in this manuscript.

Considerable effort has gone into developing putative non-nucleoside DNMT inhibitors as gene desilencing agents. Examples include flavonoids like (-)-epigallocatechin-3-gallate (EGCG) from green tea [26], genistein from soybean [27] [28], quercetin [29], the thiopurine 6-thioguanine [30], disulfiram [21], mitoxantrone [31], psammaplin A [32], hydralazine [33] [34], procainamide [33] [34], procaine [35], N-acetylprocainamide [36], arsenic trioxide [37], SGI-1027 [38], RG108 [39], and the phosphorothioate antisense oligonucleotide MG98 [40] [41] [42]. Of these, MG98 was abandoned after failure in clinical trials [43] [44]. In subsequent studies, EGCG [45] [46], hydralazine [45], procaine [46], and procainamide [45] were found to have insignificant demethylating activity. RG108 was less effective than azacytidine or decitabine, but comparable to zebularine [46].

A general consensus is that decitabine and azacytidine remain the most potent DNMT inhibitors, superior to other compounds tested [45-47]. Acridine compounds might yet offer some advantages over decitabine and azacytidine as novel non-nucleoside inhibitors of DNMT1 and gene desilencing agents. As a class, they are known to rapidly intercalate into DNA [8]. DNA intercalation by these compounds might mediate DNMT1 inhibition as well as other, not yet identified rapid biochemical events such as active DNA demethylation. Decitabine or azacytidine inhibits DNMT only after covalent incorporation into DNA, this inhibition thus requiring at least two rounds of cell division. Since acridine compounds would not require covalent incorporation into DNA for their activity, demethylation could be observed by methylation-specific PCR after only one round of cell division, as early as 6-12 hours after treatment in vitro. Our study thus identifies a promising class of lead compounds for development of gene-desilencing mehods and reprogramming of gene expression. Among other properties, these compounds are novel, fast-acting, non-nucleoside gene-desilencing agents, and optimized class members might be used to restore expression of epigenetically silenced genes in cancer cells.

\section{METHODS}

\section{Cell lines and cell culture}

MiaPaCa2 (from ATCC), HCT116 (ATCC), RKO (ATCC), and CHO AA8-Luc Tet-Off (Clontech) cells were grown in DMEM medium supplemented with $10 \%(\mathrm{v} / \mathrm{v})$ fetal bovine serum and $1 \%(\mathrm{v} / \mathrm{v})$ penicillin/streptomycin. The CHO AA8-Luc Tet-Off cell line was additionally supplemented with $100 \mu \mathrm{g} / \mathrm{ml} \mathrm{G} 418$.

\section{Compounds and drugs}

Compounds 5100018, 5175323, 5175328, 5234881, and 5238219 were obtained from ChemBridge. 5-Aza2'-deoxycytidine (decitabine), etoposide, 5-fluorouracil (5-FU), mitomycin C, quercetin, quinacrine, Scriptaid $[7,9]$, and TSA were from Sigma. Ethidium bromide was from Fisher Biotech. Compounds 5175323, 5175328, and quinacrine are further described in Table 1.

\section{Luciferase reporter assay}

Luciferase reporter assay was performed with the Promega Firefly Luciferase Assay System according to the manufacturer's protocol. Briefly, cells were plated in quadruplicate, incubated with each compound for 18 hours, and then lysed for luciferase assay. We used the PerkinElmer Microbeta Trilux plate reader to measure luminescence.

\section{Reverse transcriptase polymerase chain reaction (RT-PCR)}

Total RNA was extracted from cell populations using the Qiagen RNeasy Mini Kit and subjected to DNAse I (Invitrogen) digestion to remove contaminating DNA. $1 \mu \mathrm{g}$ of RNA was reverse-transcribed in a $20 \mu \mathrm{l}$ volume (SuperScript III First-Strand Synthesis System, Invitrogen). In a parallel tube, $1 \mu \mathrm{g}$ of RNA was treated with the cDNA synthesis reagents without the reverse transcriptase (RT) enzyme in a $20 \mu \mathrm{l}$ volume (the "no RT control"). $1 \mu 1$ of the cDNA mixture or "no RT control" was subjected to PCR amplification for 35 cycles to evaluate expression of genes of interest. Primer sequences used in RT-PCR reactions and corresponding annealing temperatures are listed in Supplementary Table S1.

\section{Methylation-specific PCR (MSP)}

Genomic DNA was extracted from cell populations (Qiagen QIAmp DNA Mini Kit). EZ DNA Methylation Kit (Zymo Research) was used for bisulfite treatment of DNA. To determine the methylation status of promoter regions, each sample of bisulfite-modified DNA was subjected to 35 cycles of PCR amplification with an annealing temp of $60^{\circ} \mathrm{C}$ using one primer pair specific for methylated DNA and another pair for unmethylated DNA. Primers used for MSP reactions are provided in Supplementary Table S2.

\section{Bisulfite sequencing}

Bisulfite-treated DNA $(\sim 100 \quad$ ng $)$ was amplified with primers encompassing the SFRP1 
transcriptional start site: SFRP1-BSeq-forward, 5'-TGGTTTTGTTTTTTAAGGGGTGTTGAGT

-3'; CTNNA1-BSeq-reverse, 5'-TCCTACCRCAAACTTCCAAAAACCT-3' with an annealing temp of $60^{\circ} \mathrm{C}$. This amplified a $429 \mathrm{bp}$ region of the $\mathrm{CpG}$ island, containing $59 \mathrm{CpG}$ sites. PCR products were separated from reagents using PCR cleanup and cloned into the pCR2.1-TOPO vector (Invitrogen). Plasmids from single colonies were purified using QIAprep Spin Miniprep Kit (Qiagen) and were sequenced with M13 reverse primers. All CpG sites (58) from the amplicon (excluding primer sequences) were analyzed.

\section{Western blot}

To prepare whole-cell extracts, cells were lysed by rocking in a detergent $(50 \mathrm{mM}$ Tris- $\mathrm{HCl}, 150 \mathrm{mM}$ $\mathrm{NaCl}, 1 \mathrm{mM}$ EDTA, $1 \%$ Triton $\mathrm{X}-100$, and a protease inhibitor cocktail (Roche)) for an hour at $4^{\circ} \mathrm{C}$ and clarified by centrifugation. The supernatant was recovered as a whole-cell extract. To prepare nuclear extracts, cells were lysed by gentle hypotonic treatment $(10 \mathrm{mM}$ HEPES pH 7.9, $1.5 \mathrm{mM} \mathrm{MgCl}, 10 \mathrm{mM} \mathrm{KCl}, 0.5 \%$ (v/v) NP40 , and protease inhibitor) and gently centrifuged. The supernatant was removed as the cytoplasmic extract. The nuclear pellet was resuspended $(50 \mathrm{mM}$ Tris- $\mathrm{HCl}, 150$ $\mathrm{mM} \mathrm{NaCl}, 1 \mathrm{mM}$ EDTA, $1 \%$ Triton X-100, and protease inhibitor). The protein concentration was determined by the DC protein assay (Bio-Rad). After adding a denaturant $(2 \%(\mathrm{~m} / \mathrm{v})$ sodium dodecyl sulfate $(\mathrm{SDS}), 10 \%(\mathrm{v} / \mathrm{v})$ glycerol, $0.002 \%(\mathrm{~m} / \mathrm{v})$ bromophenol blue, $2 \mathrm{mM}$ EDTA, $50 \mathrm{mM}$ Tris $\mathrm{pH} 6.8$, and $1 \%$ (v/v) $\beta$-mercaptoethanol), samples were boiled and resolved on a NuPAGE $4-12 \%$ Bis-Tris gel (Invitrogen). Proteins were transferred to a polyvinylidene fluoride (PVDF) membrane (Pierce). Blots were incubated with primary antibodies: antiDNMT1 (Sigma), anti-actin (Santa Cruz), or anti-acetyl histone3 lysine9 (Millipore), followed by horseradish peroxidase (HRP)-conjugated secondary antibodies (Santa Cruz): anti-rabbit $\mathrm{IgG}$, anti-goat $\mathrm{IgG}$, or anti-mouse IgG. Membranes were developed with the Immobilon substrate (Millipore). Chemi-luminescence signals were captured on HyBlot CL film (Denville).

\section{Chromatin immunoprecipitation (ChIP) assay}

Cells were crosslinked in $1 \%$ formaldehyde for 10 minutes, followed by addition of glycine for 5 minutes to quench unreacted formaldehyde. Cells were subsequently processed with the EZ-ChIP Chromatin Immunoprecipitation Kit (Millipore) according to the manufacturer's instructions. Cross-linked protein-DNA complexes were captured with anti-DNMT1 (Sigma), anti-acetyl histone3 lysine9 (Millipore), or normal rabbit IgG (Millipore) antibodies. Real-time quantitative PCR
(Bio-Rad iCycler) was performed to determine the relative abundance of the promoter DNA sequence associated with the protein of interest. Primers used for ChIP realtime quantitative PCRs and corresponding annealing temperatures are provided in Supplementary Table S3.

\section{Assay for DNMT activity}

Recombinant DNMT1 was obtained from Active Motif. The DNMT activity assay was performed using the EpiQuik DNMT Activity Assay Ultra Kit (Epigentek) according to the manufacturer's instructions.

\section{Assay for DNA intercalation}

Closed, circular pRLSV40 plasmid (3705 bp) $(0.5 \mu \mathrm{g})$ was incubated with various concentrations of each chemical in $10 \mathrm{mM}$ Tris- $\mathrm{HCl}, \mathrm{pH} 7.5$ at $37^{\circ} \mathrm{C}$ for 5 minutes [48]. An aliquot of the reaction mixture was analyzed by electrophoresis on a $0.6 \%$ agarose gel at $4^{\circ} \mathrm{C}$. The gel was incubated in ethidium bromide for 30 minutes and photographed under UV light.

\section{ACKNOWLEDGEMENTS}

Grateful thanks are due to Heather O'Hagan and Nora L. Steinbergs for their help with ChIP assay and DNMT activity assay, respectively.

\section{Grant Support}

Supported by NIH grant CA62924 and by the Everett and Marjorie Kovler Professorship in Pancreas Cancer Research.

\section{REFERENCES}

1. Herman JG and Baylin SB. Gene silencing in cancer in association with promoter hypermethylation. N Engl J Med. 2003; 349(21):2042-2054.

2. Jenuwein $\mathrm{T}$ and Allis CD. Translating the histone code. Science. 2001; 293(5532):1074-1080.

3. Strahl BD and Allis CD. The language of covalent histone modifications. Nature. 2000; 403(6765):41-45.

4. Cohen DE and Melton D. Turning straw into gold: directing cell fate for regenerative medicine. Nat Rev Genet. 12(4):243-252.

5. Christman JK. 5-Azacytidine and 5-aza-2'-deoxycytidine as inhibitors of DNA methylation: mechanistic studies and their implications for cancer therapy. Oncogene. 2002; 21(35):5483-5495.

6. Cameron EE, Bachman KE, Myohanen S, Herman JG and Baylin SB. Synergy of demethylation and histone 
deacetylase inhibition in the re-expression of genes silenced in cancer. Nat Genet. 1999; 21(1):103-107.

7. Cunningham SC, Ryu B, Sohn TA and Kern SE. Nonspecific enhancement of gene expression by compounds identified in high-throughput cell-based screening. Biotechniques. 2004; 37(1):120-122.

8. Sebestik J, Hlavacek J and Stibor I. A role of the 9-aminoacridines and their conjugates in a life science. Curr Protein Pept Sci. 2007; 8(5):471-483.

9. Su GH, Sohn TA, Ryu B and Kern SE. A novel histone deacetylase inhibitor identified by high-throughput transcriptional screening of a compound library. Cancer Res. 2000; 60(12):3137-3142.

10. Sakai M, Hibi K, Koshikawa K, Inoue S, Takeda S, Kaneko $\mathrm{T}$ and Nakao A. Frequent promoter methylation and gene silencing of CDH13 in pancreatic cancer. Cancer Sci. 2004; 95(7):588-591.

11. Winter JM, Ting AH, Vilardell F, Gallmeier E, Baylin SB, Hruban RH, Kern SE and Iacobuzio-Donahue CA. Absence of E-cadherin expression distinguishes noncohesive from cohesive pancreatic cancer. Clin Cancer Res. 2008; 14(2):412-418.

12. Schutte M, Hruban RH, Geradts J, Maynard R, Hilgers W, Rabindran SK, Moskaluk CA, Hahn SA, SchwarteWaldhoff I, Schmiegel W, Baylin SB, Kern SE and Herman JG. Abrogation of the Rb/p16 tumor-suppressive pathway in virtually all pancreatic carcinomas. Cancer Res. 1997; 57(15):3126-3130.

13. Suzuki H, Watkins DN, Jair KW, Schuebel KE, Markowitz SD, Chen WD, Pretlow TP, Yang B, Akiyama Y, Van Engeland M, Toyota M, Tokino T, Hinoda Y, Imai K, Herman JG and Baylin SB. Epigenetic inactivation of SFRP genes allows constitutive WNT signaling in colorectal cancer. Nat Genet. 2004; 36(4):417-422.

14. Sato N, Parker AR, Fukushima N, Miyagi Y, IacobuzioDonahue CA, Eshleman JR and Goggins M. Epigenetic inactivation of TFPI-2 as a common mechanism associated with growth and invasion of pancreatic ductal adenocarcinoma. Oncogene. 2005; 24(5):850-858.

15. Schuebel KE, Chen W, Cope L, Glockner SC, Suzuki H, Yi JM, Chan TA, Van Neste L, Van Criekinge W, van den Bosch S, van Engeland M, Ting AH, Jair K, Yu W, Toyota $\mathrm{M}$, Imai K, et al. Comparing the DNA hypermethylome with gene mutations in human colorectal cancer. PLoS Genet. 2007; 3(9): 1709-1723.

16. Ghoshal K, Datta J, Majumder S, Bai S, Kutay H, Motiwala $\mathrm{T}$ and Jacob ST. 5-Aza-deoxycytidine induces selective degradation of DNA methyltransferase 1 by a proteasomal pathway that requires the KEN box, bromo-adjacent homology domain, and nuclear localization signal. Mol Cell Biol. 2005; 25(11):4727-4741.

17. Sallinen J, Hoglund I, Engstrom M, Lehtimaki J, Virtanen R, Sirvio J, Wurster S, Savola JM and Haapalinna A. Pharmacological characterization and CNS effects of a novel highly selective alpha2C-adrenoceptor antagonist JP-1302. Br J Pharmacol. 2007; 150(4):391-402.

18. Harle DG and Baldo BA. Structural features of potent inhibitors of rat kidney histamine N-methyltransferase. Biochem Pharmacol. 1988; 37(3):385-388.

19. Gallant JN, Allen JE, Smith CD, Dicker DT, Wang W, Dolloff NG, Navaraj A and El-Deiry WS. Quinacrine synergizes with 5-fluorouracil and other therapies in colorectal cancer. Cancer Biol Ther. 12(3):239-251.

20. Wang W, Gallant JN, Katz SI, Dolloff NG, Smith CD, Abdulghani J, Allen JE, Dicker DT, Hong B, Navaraj A and El-Deiry WS. Quinacrine sensitizes hepatocellular carcinoma cells to TRAIL and chemotherapeutic agents. Cancer Biol Ther. 12(3):229-238.

21. Lin J, Haffner MC, Zhang Y, Lee BH, Brennen WN, Britton J, Kachhap SK, Shim JS, Liu JO, Nelson WG, Yegnasubramanian S and Carducci MA. Disulfiram is a DNA demethylating agent and inhibits prostate cancer cell growth. Prostate. 71(4):333-343.

22. Mercurio C, Minucci S and Pelicci PG. Histone deacetylases and epigenetic therapies of hematological malignancies. Pharmacol Res. 62(1):18-34.

23. Huang Y, Greene E, Murray Stewart T, Goodwin AC, Baylin SB, Woster PM and Casero RA, Jr. Inhibition of lysine-specific demethylase 1 by polyamine analogues results in reexpression of aberrantly silenced genes. Proc Natl Acad Sci U S A. 2007; 104(19):8023-8028.

24. Liu F, Chen X, Allali-Hassani A, Quinn AM, Wasney GA, Dong A, Barsyte D, Kozieradzki I, Senisterra G, Chau I, Siarheyeva A, Kireev DB, Jadhav A, Herold JM, Frye $\mathrm{SV}$, Arrowsmith CH, et al. Discovery of a 2,4-diamino-7aminoalkoxyquinazoline as a potent and selective inhibitor of histone lysine methyltransferase G9a. J Med Chem. 2009; 52(24):7950-7953.

25. Huang HS, Allen JA, Mabb AM, King IF, Miriyala J, Taylor-Blake B, Sciaky N, Dutton JW, Lee HM, Chen X, Jin J, Bridges AS, Zylka MJ, Roth BL and Philpot BD. Topoisomerase inhibitors unsilence the dormant allele of Ube3a in neurons. Nature.

26. Fang MZ, Wang Y, Ai N, Hou Z, Sun Y, Lu H, Welsh $\mathrm{W}$ and Yang CS. Tea polyphenol (-)-epigallocatechin-3gallate inhibits DNA methyltransferase and reactivates methylation-silenced genes in cancer cell lines. Cancer Res. 2003; 63(22):7563-7570.

27. Fang MZ, Chen D, Sun Y, Jin Z, Christman JK and Yang CS. Reversal of hypermethylation and reactivation of p16INK4a, RARbeta, and MGMT genes by genistein and other isoflavones from soy. Clin Cancer Res. 2005; 11(19 Pt 1):7033-7041.

28. Day JK, Bauer AM, DesBordes C, Zhuang Y, Kim BE, Newton LG, Nehra V, Forsee KM, MacDonald RS, Besch-Williford C, Huang TH and Lubahn DB. Genistein alters methylation patterns in mice. J Nutr. 2002; 132(8 Suppl):2419S-2423S. 
29. Tan S, Wang C, Lu C, Zhao B, Cui Y, Shi X and Ma X. Quercetin is able to demethylate the p16INK4a gene promoter. Chemotherapy. 2009; 55(1):6-10.

30. Yuan B, Zhang J, Wang H, Xiong L, Cai Q, Wang T, Jacobsen S, Pradhan S and Wang Y. 6-Thioguanine reactivates epigenetically silenced genes in acute lymphoblastic leukemia cells by facilitating proteasomemediated degradation of DNMT1. Cancer Res. 71(5):19041911.

31. Parker BS, Cutts SM, Nudelman A, Rephaeli A, Phillips DR and Sukumar S. Mitoxantrone mediates demethylation and reexpression of cyclin $\mathrm{d} 2$, estrogen receptor and 14.3.3sigma in breast cancer cells. Cancer Biol Ther. 2003; 2(3):259-263.

32. Pina IC, Gautschi JT, Wang GY, Sanders ML, Schmitz FJ, France D, Cornell-Kennon S, Sambucetti LC, Remiszewski SW, Perez LB, Bair KW and Crews P. Psammaplins from the sponge Pseudoceratina purpurea: inhibition of both histone deacetylase and DNA methyltransferase. J Org Chem. 2003; 68(10):3866-3873.

33. Cornacchia E, Golbus J, Maybaum J, Strahler J, Hanash S and Richardson B. Hydralazine and procainamide inhibit $\mathrm{T}$ cell DNA methylation and induce autoreactivity. J Immunol. 1988; 140(7):2197-2200.

34. Segura-Pacheco B, Trejo-Becerril C, Perez-Cardenas E, Taja-Chayeb L, Mariscal I, Chavez A, Acuna C, Salazar AM, Lizano M and Duenas-Gonzalez A. Reactivation of tumor suppressor genes by the cardiovascular drugs hydralazine and procainamide and their potential use in cancer therapy. Clin Cancer Res. 2003; 9(5):1596-1603.

35. Villar-Garea A, Fraga MF, Espada $\mathrm{J}$ and Esteller $\mathrm{M}$. Procaine is a DNA-demethylating agent with growthinhibitory effects in human cancer cells. Cancer Res. 2003; 63(16):4984-4989.

36. Richardson B, Cornacchia E, Golbus J, Maybaum J, Strahler J and Hanash S. N-acetylprocainamide is a less potent inducer of $\mathrm{T}$ cell autoreactivity than procainamide. Arthritis Rheum. 1988; 31(8):995-999.

37. Fu HY, Shen JZ, Wu Y, Shen SF, Zhou HR and Fan LP. Arsenic trioxide inhibits DNA methyltransferase and restores expression of methylation-silenced CDKN2B/ CDKN2A genes in human hematologic malignant cells. Oncol Rep. 24(2):335-343.

38. Datta J, Ghoshal K, Denny WA, Gamage SA, Brooke DG, Phiasivongsa P, Redkar S and Jacob ST. A new class of quinoline-based DNA hypomethylating agents reactivates tumor suppressor genes by blocking DNA methyltransferase 1 activity and inducing its degradation. Cancer Res. 2009; 69(10):4277-4285.

39. Brueckner B, Garcia Boy R, Siedlecki P, Musch T, Kliem HC, Zielenkiewicz P, Suhai S, Wiessler M and Lyko F. Epigenetic reactivation of tumor suppressor genes by a novel small-molecule inhibitor of human DNA methyltransferases. Cancer Res. 2005; 65(14):6305-6311.
40. Amato RJ. Inhibition of DNA methylation by antisense oligonucleotide MG98 as cancer therapy. Clin Genitourin Cancer. 2007; 5(7):422-426.

41. Davis AJ, Gelmon KA, Siu LL, Moore MJ, Britten CD, Mistry N, Klamut H, D'Aloisio S, MacLean M, Wainman N, Ayers D, Firby P, Besterman JM, Reid GK and Eisenhauer EA. Phase I and pharmacologic study of the human DNA methyltransferase antisense oligodeoxynucleotide MG98 given as a 21-day continuous infusion every 4 weeks. Invest New Drugs. 2003; 21(1):8597.

42. Stewart DJ, Donehower RC, Eisenhauer EA, Wainman N, Shah AK, Bonfils C, MacLeod AR, Besterman JM and Reid GK. A phase I pharmacokinetic and pharmacodynamic study of the DNA methyltransferase 1 inhibitor MG98 administered twice weekly. Ann Oncol. 2003; 14(5):766774.

43. Klisovic RB, Stock W, Cataland S, Klisovic MI, Liu S, Blum W, Green M, Odenike O, Godley L, Burgt JV, Van Laar E, Cullen M, Macleod AR, Besterman JM, Reid GK, Byrd JC, et al. A phase I biological study of MG98, an oligodeoxynucleotide antisense to DNA methyltransferase 1 , in patients with high-risk myelodysplasia and acute myeloid leukemia. Clin Cancer Res. 2008; 14(8):24442449.

44. Winquist E, Knox J, Ayoub JP, Wood L, Wainman N, Reid GK, Pearce L, Shah A and Eisenhauer E. Phase II trial of DNA methyltransferase 1 inhibition with the antisense oligonucleotide MG98 in patients with metastatic renal carcinoma: a National Cancer Institute of Canada Clinical Trials Group investigational new drug study. Invest New Drugs. 2006; 24(2):159-167.

45. Chuang JC, Yoo CB, Kwan JM, Li TW, Liang G, Yang AS and Jones PA. Comparison of biological effects of nonnucleoside DNA methylation inhibitors versus 5-aza-2'deoxycytidine. Mol Cancer Ther. 2005; 4(10):1515-1520.

46. Stresemann C, Brueckner B, Musch T, Stopper H and Lyko F. Functional diversity of DNA methyltransferase inhibitors in human cancer cell lines. Cancer Res. 2006; 66(5):27942800.

47. Fathi AT and Abdel-Wahab O. Mutations in epigenetic modifiers in myeloid malignancies and the prospect of novel epigenetic-targeted therapy. Adv Hematol. 2012:469592.

48. Ahmed MS, Ramesh V, Nagaraja V, Parish JH and Hadi SM. Mode of binding of quercetin to DNA. Mutagenesis. 1994; 9(3):193-197. 